Original Article

\title{
Incidence and Pattern of Bacterial Growth in Propofol Vial - An In vitro Study
}

\author{
U.S. Raveendra ${ }^{1}$, Rashmi Soori ${ }^{2}$, Vimal Kumar Karnekar ${ }^{3}$, Swathi N. Nayak ${ }^{4} \&$ Anand Bangera $^{5}$ \\ ${ }^{1}$ Professor, ${ }^{2}$ Assistant Professor, ${ }^{5}$ Professor and Head, Department of Anaesthesiology, ${ }^{3}$ Professor and Head, Department of \\ Microbiology, K.S. Hegde M edical Academy, M angalore \\ ${ }^{4}$ Consultant, Department of M icrobiology, Adarsha Hospital, Kundapur.
}

*Corresponding Author : Rashmi Soori, C-001, KSHEM A Staff quarters, Deralakatte, Mangalore

Mobile : +91 8050152374 E-mail : drrashmisoori@gmail.com

$\begin{array}{ll}\text { Received } & : \text { 01-12-2015 } \\ \text { Review Completed } & : \text { 13-05-2016 } \\ \text { Accepted } & : 14-05-2016\end{array}$

Keywords : Propofol, Contamination, Bacterial growth

\begin{tabular}{|c|}
\hline Access this article online \\
\hline Quick Response Code \\
\hline
\end{tabular}

\begin{abstract}
:
Introduction- Propofol vials are often used in parts or are opened and left unattended. This has lead to blood stream infections, surgical site infections and acute febrile episodes. A prospective observational study was undertaken to know the incidence and pattern of bacterial growth in samples of Propofol in tropical climate.
\end{abstract}

\begin{abstract}
Materials and methods- Samples were collected from vials of propofol of different brands, both with and without edetate at different time intervals with relation to room temperature. Each sample of $1 \mathrm{ml}$ were inoculated in Brain Heart Infusion (BHI) and incubated for 48hours. Presence of bacterial growth and their pattern were studied.
\end{abstract}
Statistical analysis used- Paired t test for categorical variables and for non categorical variables Levine's test and Pearson correlation.

Results- Overall $42.26 \%$ of samples showed bacterial growth. The incidence was more in samples of propofol without edetate (43.75\%) compared to samples with edetate $(41.97 \%)$. Most common organism was Staphylococcus aureus, followed by Enterococcus, Acinetobacter, Bacillus species, Pseudomonas and Staphylococcus citrus.

Conclusion- Propofol vial once opened favours bacterial colonisation and growth. Adding edetate to propofol has not shown much benefit in decreasing the incidence.

\section{Introduction}

Propofol, being a lipid emulsion, is a good medium for bacterial growth. Adhering to manufacturer's recommendations of "use without delay" is often difficult. This is because of the need to use small quantity of the drug during general anaesthesia, such as to reduce the intubation response, increase the depth of anaesthesia, prevention of extubation response and laryngospasm in addition to induction of anaesthesia. This results in a delay between opening of the vial and using the last portion of the drug. Extrinsic contamination of propofol by various microorganisms has been associated with outbreaks of bloodstream infections, surgical site infections, and acute febrile episodes $s^{1,2,3,4}$

Available literature regarding bacterial growth in propofol as such and effect of additives such as edetate is scanty. Further, the pattern of bacteria also depends on the geographic location and temperature. Hence, a study was undertaken to find out the pattern of bacterial growth in a series of randomly selected samples of propofol.

\section{Materials and methods}

A prospective observational study was conducted in department of Anaesthesiology in association with department of $\mathrm{M}$ icrobiology in a tertiary care hospital. The study was conducted with the aim to determine the incidence of growth of microorganisms in samples of propofol in tropical climate, the pattern of microbial growth and any difference in incidence between samples of propofol with or without edetate. The study sample was collected from different operation theatres. Vials of 
propofol, both with and without edetate were used for the study. The opening time of all the vials, from which samples were obtained, was noted. Subsequently, series of samples were taken at different intervals starting from immediately after opening the vial to as long as 6 hrs 30 minutes. The samples were collected using 2cc syringe with aseptic precautions. Each sample of $1 \mathrm{ml}$ was inoculated in Brain Heart Infusion (BHI) in cork screw bottles and the theatre temperature was noted. The cork screw bottles were transported to microbiology laboratory. The incubation in the microbiology department was performed within 30 minutes of inoculation in the transport media - Brain Heart Infusion. Incubation was performed in blood agar and McConkey agar at 37 degree Celsius for 48 hours. The incubated samples were then evaluated for the presence of microorganism by standard microbiological procedures and the organism was identified. If there were no organisms grown, the samples were kept incubated and evaluated for the presence of organism after 72 hours. The flora grown from routine sampling of operation theatres were Staphylococcus aureus and Bacillus species being the commonest, followed by coagulase negative Staphylococcus species and non-fermenters of gram negative bacilli respectively.

\section{Results}

Out of one hundred, 3 samples were lost while transferring from OT complex to microbiology laboratory. Final analysis included 97 samples. Statistical analysis was performed using Paired t test for categorical variables and non categorical by Levene test and Pearson correlation. No correlation was found either between openings of the propofol vial and inoculation time (Table $1 \&$ Table 3, Graph 1) or between differences of the temperature and bacterial isolation (Table 2). Total of 41 samples among 97 studied showed bacterial growth (42.26\%). In propofol vials without edetate, organisms were grown in $43.75 \%$ (7 samples in 16) whereas in propofol vials with edetate, incidence was $41.97 \%$ (34 samples in 81) (Table 4). However the difference in incidence between the samples with and without edetate was not statistically significant ( $p$ value $>0.005$ ) One sample without edetate grew two species of bacteria, Staphylococcus and Bacillus species. M ost common organism was Staphylococcus aureus (70\%), followed by Enterococcus (12\%), Acinetobacter (7\%) and Bacillus species, Pseudomonas and Staphylococcus citreus (Table 4).

Table 1 : Correlation between opening time and inoculation time

\begin{tabular}{|l|l|c|c|}
\hline & & $\begin{array}{c}\text { Opening } \\
\text { time }\end{array}$ & $\begin{array}{c}\text { Inoculation } \\
\text { time }\end{array}$ \\
\hline $\begin{array}{l}\text { Opening } \\
\text { time }\end{array}$ & $\begin{array}{l}\text { Pearson correlation } \\
\text { sig. (2-tailed) }\end{array}$ & 1 & 0.584-0.000 \\
\hline & $\mathrm{N}$ & 100 & 100 \\
\hline $\begin{array}{l}\text { Inoculation } \\
\text { time }\end{array}$ & $\begin{array}{l}\text { Pearson correlation } \\
\text { sig. (2-tailed) }\end{array}$ & $0.584-0.000$ & 1 \\
\hline & $\mathrm{N}$ & 100 & 100 \\
\hline
\end{tabular}

Correlation is significant at the level 0.01 (2- tailed)

Table 2 : Correlation between Temperature difference and bacterial growth Group statistics

\begin{tabular}{|c|c|c|c|c|c|}
\hline Temperature & Edetate & $\mathrm{N}$ & Mean & $\begin{array}{c}\text { Standard } \\
\text { deviation }\end{array}$ & $\begin{array}{c}\text { Standard error } \\
\text { M ean }\end{array}$ \\
\hline & Present & 83 & 23.42 & 3.190 & 0.350 \\
\cline { 2 - 6 } & Absent & 17 & 23.12 & 1.409 & 0.342 \\
\hline
\end{tabular}

Independent samples test

\begin{tabular}{|l|l|c|c|c|c|c|}
\hline & & $\begin{array}{c}\text { Levene's test } \\
\text { of equality } \\
\text { of variances }\end{array}$ & \multicolumn{4}{|c|}{$\begin{array}{c}\text { t-test for } \\
\text { equality } \\
\text { of means }\end{array}$} \\
\hline Temperature & $\begin{array}{c}\text { Equal variances } \\
\text { assumed }\end{array}$ & 4.755 & 0.032 & 0.384 & 98 & 0.702 \\
\cline { 2 - 8 } & $\begin{array}{l}\text { Equal variances } \\
\text { not assumed }\end{array}$ & & & 0.621 & 55.322 & 0.537 \\
\hline
\end{tabular}

Independent samples test

\begin{tabular}{|c|c|c|c|c|c|}
\hline & & \multicolumn{4}{|c|}{ t-test for equality of means } \\
\hline & & \multirow[t]{2}{*}{$\begin{array}{c}\text { Mean } \\
\text { difference }\end{array}$} & \multirow[t]{2}{*}{$\begin{array}{c}\text { Standard } \\
\text { error } \\
\text { difference }\end{array}$} & \multicolumn{2}{|c|}{$\begin{array}{c}95 \% \text { confidence } \\
\text { interval of the } \\
\text { difference }\end{array}$} \\
\hline & & & & lower & upper \\
\hline \multirow[t]{2}{*}{$\begin{array}{l}\text { Tempe } \\
\text { rature }\end{array}$} & $\begin{array}{l}\text { Equal variances } \\
\text { assumed }\end{array}$ & 0.304 & 0.791 & -1.266 & 1.875 \\
\hline & $\begin{array}{l}\text { Equal variances } \\
\text { not assumed }\end{array}$ & 0.304 & 0.489 & -0.676 & 1.284 \\
\hline
\end{tabular}

Table 3 : Difference in bacterial growth depending upon inoculation time and opening time of the vial Group statistics

\begin{tabular}{|l|l|l|l|l|c|}
\hline Difference between & Edetate & $\mathrm{N}$ & M ean & $\begin{array}{l}\text { Standard } \\
\text { deviation }\end{array}$ & $\begin{array}{c}\text { Standard } \\
\text { error M ean }\end{array}$ \\
\cline { 2 - 6 } $\begin{array}{l}\text { the inoculation } \\
\text { time and opening }\end{array}$ & Present & 83 & 2.6537 & 1.93182 & 0.21204 \\
\cline { 2 - 6 } time & Absent & 17 & 2.7518 & 1.35054 & 0.32755 \\
\hline
\end{tabular}


Independent samples test

\begin{tabular}{|l|l|c|c|c|c|c|}
\hline & & \multicolumn{2}{|c|}{$\begin{array}{c}\text { Levene's test } \\
\text { of equality } \\
\text { of variances }\end{array}$} & \multicolumn{3}{|c|}{$\begin{array}{c}\text { t-test for } \\
\text { equality } \\
\text { of means }\end{array}$} \\
\hline $\mathrm{f}$ & Sig. & $\mathrm{t}$ & $\mathrm{df}$ & $\begin{array}{c}\text { Sig. } \\
\text { (2-tailed) }\end{array}$ \\
\hline $\begin{array}{l}\text { Difference } \\
\text { between the } \\
\text { inoculation } \\
\text { time and } \\
\text { opening time }\end{array}$ & $\begin{array}{l}\text { Equal variances } \\
\text { assumed }\end{array}$ & 6.661 & 0.011 & -0.199 & 98 & 0.843 \\
\cline { 2 - 7 } & $\begin{array}{l}\text { Equal variances } \\
\text { nossumed }\end{array}$ & & & -0.251 & 31.153 & 0.803 \\
\hline
\end{tabular}

Independent samples test

\begin{tabular}{|c|c|c|c|c|c|}
\hline & & \multicolumn{4}{|c|}{ t-test for equality of means } \\
\hline & & \multirow[t]{2}{*}{$\begin{array}{c}\text { Mean } \\
\text { difference }\end{array}$} & \multirow[t]{2}{*}{$\begin{array}{c}\text { Standard } \\
\text { error } \\
\text { difference }\end{array}$} & \multicolumn{2}{|c|}{$\begin{array}{c}\text { 95\% confidence } \\
\text { interval of the } \\
\text { difference }\end{array}$} \\
\hline & & & & lower & upper \\
\hline \multirow{2}{*}{\begin{tabular}{|l|} 
Difference \\
between the \\
inoculation \\
time and \\
opening time
\end{tabular}} & $\begin{array}{l}\text { Equal } \\
\text { variances } \\
\text { assumed }\end{array}$ & -0.09803 & 0.49235 & -1.07509 & \\
\hline & $\begin{array}{l}\text { Equal } \\
\text { variances } \\
\text { Not } \\
\text { assumed }\end{array}$ & -0.09803 & 0.39020 & -0.89369 & 0.69763 \\
\hline
\end{tabular}

Table 4 : Difference in bacterial growth depending on whether edetate present or absent Case processing summary

\begin{tabular}{|c|c|c|c|c|c|c|}
\hline \multirow{3}{*}{$\begin{array}{l}\text { Time of } \\
\text { inoculation } \\
0 \text { to } 30 \mathrm{~min}\end{array}$} & \multicolumn{3}{|c|}{ Samples with edetate } & \multicolumn{3}{|c|}{ Samples without edetate } \\
\hline & \multirow{2}{*}{$\begin{array}{l}\text { Total } \\
7\end{array}$} & \multicolumn{2}{|c|}{ Organism present } & \multirow{2}{*}{$\begin{array}{c}\text { Total } \\
0\end{array}$} & \multicolumn{2}{|c|}{ Organi\$m present } \\
\hline & & Nil & - & & nil & - \\
\hline $30 \mathrm{~min}$ to $90 \mathrm{~min}$ & 25 & 13 & \begin{tabular}{|l|}
$11-$ Staph aureus \\
1-Enterococcus \\
1-Pseudomonas
\end{tabular} & 4 & 3 & $\begin{array}{l}\text { 3-Staph aureus } \\
\text { 1- missing }\end{array}$ \\
\hline $90 \mathrm{~min}$ to $150 \mathrm{~min}$ & 15 & 9 & $\begin{array}{l}\text { 2-Enterococcus } \\
\text { 1-Bacillus sp } \\
\text { 1-Staph aureus } \\
\text { 1- Staph citreus } \\
\text { 1-Acinetobacter }\end{array}$ & 5 & 3 & $\begin{array}{l}\text { 1-Enterococcus } \\
\text { 1-Staph aureus } \\
\text { 1-Staph aureus and Bacillus species }\end{array}$ \\
\hline $150 \mathrm{~min}$ to $270 \mathrm{~min}$ & 20 & 6 & $\begin{array}{l}\text { 5-Staph aureus } \\
\text { 1-Acinetobacter } \\
\text { 1-missing }\end{array}$ & 6 & 1 & 1-Staph aureus \\
\hline $270 \mathrm{~min}$ to $390 \mathrm{~min}$ & 16 & 6 & $\begin{array}{l}\text { 4-staph aureus } \\
\text { 1-Acinetobacter } \\
\text { 1-Enterococcus } \\
\text { 1- missing }\end{array}$ & 2 & nil & \\
\hline
\end{tabular}

\begin{tabular}{|c|c|c|c|c|c|}
\hline \multicolumn{5}{|c|}{ Samples } \\
\hline \multicolumn{2}{|c|}{ valid } & \multicolumn{2}{|c|}{ missing } & \multicolumn{2}{c|}{ Total } \\
\hline $\mathrm{N}$ & Percentage & $\mathrm{N}$ & Percentage & $\mathrm{N}$ & Percentage \\
\hline 97 & $97 \%$ & 3 & $3 \%$ & 100 & $100 \%$ \\
\hline
\end{tabular}

Graph 1 : Correlation between opening time and inoculation time

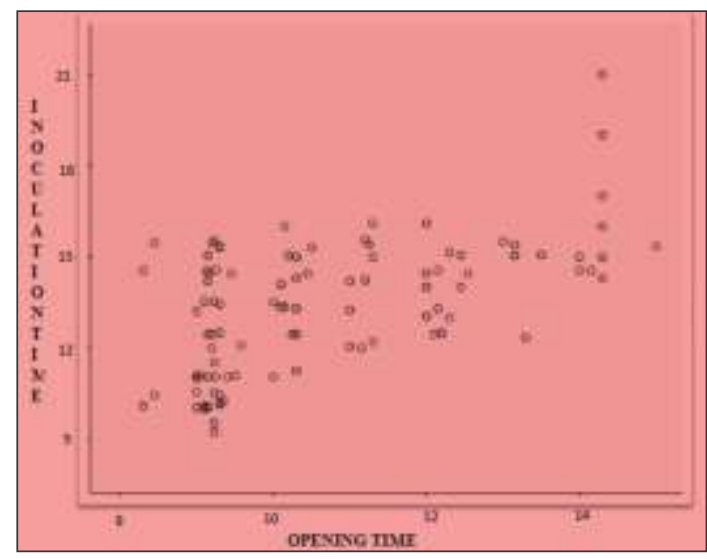

\begin{tabular}{|c|c|c|c|c|}
\hline \multicolumn{2}{|c|}{} & \multicolumn{2}{|c|}{ Organism } & Total \\
\cline { 3 - 5 } \multicolumn{2}{|c|}{} & Present & Absent & \\
\hline \multirow{2}{*}{ Edetate } & Present & 34 & 47 & 81 \\
\cline { 2 - 5 } & Absent & 7 & 9 & 16 \\
\hline Total & 41 & 56 & 97 & \\
\hline
\end{tabular}

\section{Discussion}

The day-to-day practicalities of clinical anaesthesia dictate that some delay between the opening of propofol and its injection into the patient is unavoidable. Further, these delays are variable in both duration and causation. Our study compared the incidence of bacterial growth in propofol vials from immediately after opening of the vial up to 390 minutes after opening the vial. Bacterial contamination was observed in $42.26 \%$ of samples, significantly more compared to other studies which reported incidence rates ranging from $6.3 \%$ to $26 \%$. One of 
the reasons for lower incidence rates in the previous studies were due to immediate inoculation after opening the vial with the maximum time being up to 90 minutes ${ }^{5}$. However, even in our study, there was no statistically significant difference in incidence of bacterial growth with different time intervals of opening and inoculation. This finding is consistent with those of previous studies ${ }^{5}$.

\section{Type of bacteria}

Overall, Staphylococcus aureus (70\%) was the most common organism, followed by Enterococcus (12\%), Acinetobacter (7\%) and Bacillusspecies, Pseudomonas and Staphylococcus citrius in our study. Previous studies ${ }^{5}$ have also shown Staphylococcus species was the commonest isolated organism followed by Diphteroids, Micrococcus and Bacillus species. One sample had grown two species of bacteria, Staphylococcus and Bacillus species.

Staphylococcus aureus is both a commensal organism and a pathogen. The anterior nares are the main ecological niche for S. aureus ${ }^{6}$. Approximately $20 \%$ of individuals are persistently nasally colonized with S. aureus, and $30 \%$ are intermittently colonized. However, other sites may be colonized, including the axillae, groin, and gastrointestinal tract. Colonization provides a reservoir from which bacteria can be introduced when host defences are breached, whether by shaving, aspiration, insertion of an indwelling catheter, or surgery. Colonization clearly increases the risk for subsequent infection ${ }^{6,7,8}$.

Bacillus species are common contaminating organisms of addicts' heroin and injection paraphernalia, due to their ubiquity in natural, domestic and hospital environments and their production of resistant endospores ${ }^{9}$. Reports of "pseudo-outbreaks" of Bacillus species is connected with contaminated clinical and laboratory equipment ${ }^{9}$.

One study ${ }^{1}$ isolated Moraxella osloensis, Enterobacter agglomerans and Serratia marcescens from opened propofol vials. Studies have shown that propofol supports the growth of Staphylococcus species ${ }^{10,11}$, Candida albicans $^{10,11}$, Moraxella osloensis ${ }^{10}$ and Pseudomonas aeruginosa ${ }^{11}$.Another study ${ }^{12}$ showed that propofol strongly supports the growth of E. coli and C. albicans but is bacteriostatic toward $\mathrm{S}$. aureus and weakly bactericidal toward $P$. aeruginosa.

Staphylococcus aureus, epidermidis, diphteroids were the bacterial strains isolated from propofol by preparation technique similar to the clinical practice in a study ${ }^{13}$.

Enterococci are a part of the normal human faecal flora. Sites less often colonized are the oral cavity, genitourinary tract and skin especially in the perineal area. The main sites of colonization in the hospitalized patients are soft tissue wounds, ulcers and the gastrointestinal tract (GIT) ${ }^{14}$. Enterococci have emerged as an important cause of nosocomial infections. These infections are recognized by 3 ts - tough, tenacious and often troublesome ${ }^{14,15}$. The most frequent infections caused by enterococci are urinary tract infections ${ }^{14,16}$. The second most frequent enterococcal infections are intra - abdominal and intra - pelvic abscesses or post-surgery wound infections ${ }^{14,16}$. The third most frequent infection caused by these organisms is blood stream infections $s^{14,17}$. Other infections caused with lower frequency are central nervous system (CNS) and neonatal infections. Enterococci rarely cause respiratory tract infections, osteomyelitis, or cellulitis ${ }^{14,18}$.

The gram-negative coccobacillus, Acinetobacter, a pathogen once seen only in hot, humid climates, has become an increasingly common nosocomial problem even in temperate climates $^{19}$. The association of A.baumannii with pneumonia, bacteremia, wound infections, urinary tract infections, and meningitis has been well described ${ }^{20,21}$. Risk factors asso ciated with colonization or infection (which can be difficult to distinguish) include prolonged hospitalization, intensive care unit admission, recent surgical procedures, antimicrobial agent exposure, central venous catheter use, prior hospitalization, nursing home residence, and local colonization pressure on susceptible patients ${ }^{20,21}$.

The prevalence of colonisation by $\mathrm{P}$. aeruginosa in healthy subjects is usually low, but higher colonisation rates can be encountered following hospitalisation, especially amongst 
subjects treated with broad-spectrum antimicrobial agents. Colonisation is common in the respiratory tract of mechanically ventilated patients, in the gastrointestinal tract of patients receiving anticancer chemotherapy, and on the skin of burn patients ${ }^{22}$. Also, sinks, mops, disinfectant solutions, respiratory equipment, food mixers and other moist environments can act as reservoirs of $P$. aeruginosa in the hospital setting $\mathrm{g}^{22,23,24}$.

\section{Staphylococcus citreus occurs as the normal flora of nose in upto $1 \%$ and normal flora of throat in $15-25 \%$.}

The difference in type of bacteria compared to previous studies ${ }^{1,5,13}$ could be explained by geographical differences and local practices between the present and previous study locations.

\section{Effect of edetate}

Our study did not show statistically significant difference in incidence ( $p$ value $=1$ ) between bacterial growth in propofol vials with and without edetate. With absence of edetate

\section{Referances}

1. Bennett SN, M cNeil M M , Bland LA, Arduino MJ, Villarino ME, Perrotta $\mathrm{DM}$ et al. Postoperative infections traced to contamination of an intravenous anesthetic, propofol. New England Journal of Medicine. 1995; 333:147-54

2. Vidovich MI, Peterson LR, Wong HY. The effect of lidocaine on bacterial growth in propofol. Anesth Analg 1999; 88: 936-8.

3. Postsurgical infections associated with an extrinsically contaminated intravenous anesthetic agent-California, Illinois, Maine, and M ichigan, 1990. M M WR M orb M ortal Wkly Rep 1990; 39: 426-7,433.

4. Kuehnert MJ, Webb RM, Jochimsen EM, Hancock GA, Arduino MJ, Hand $S$ et al. Staphylococcus aureus bloodstream infections among patients undergoing electroconvulsive therapy traced to breaks in infection control and possible extrinsic contamination by propofol. Anesth Analg 1997;85:420-5.

5. McHugh GJ, Roper GM. Propofol emulsion and bacterial contamination.Can J Anaesth 1995; 42: 801-4.

6. Gordon RJ, Lowy FD. Pathogenesis of methicillin-resistant Staphylococcus aureus infection. Clinical infectious diseases. 2008; 46(Supplement 5):S350-9.

7. Wertheim HF, Melles DC, Vos MC, van Leeuwen W, van Belkum A, Verbrugh HA et al. The role of nasal carriage in Staphylococcus aureus infections. The Lancet infectious diseases. 2005; 5:751-62.

8. Kluytmans J, Van Belkum A, Verbrugh $H$. Nasal carriage of Staphylococcus aureus: epidemiology, underlying mechanisms, and associated risks. Clinical microbiology reviews. 1997; 10:505-20.

9. Logan NA. Bacillus species of medical and veterinary importance. Journal of medical microbiology. 1988; 25:157-65.

10. Tessler M, Dascal A, Gioseffini S, M iller M , M endelson J. Growth curves of Staphylococcus aureus, Candida albicans, and M oraxella osloensis in propofol and other media. Canadian journal of anaesthesia. 1992; 39:509-11.

11. Berry CB, Gillespie T, Hood J, Scott NB. Growth of micro-organisms in solutions of intravenous anaesthetic agents. Anaesthesia. 1993; vials organism were found in $43.75 \%$ versus $41.97 \%$. Sticking to propofol handling guidelines ${ }^{26}$ including hand wash may help in decreasing the incidence of bacterial growth in propofol vials. Edetate has proven to have inhibitory effect on bacterial growth ${ }^{27}$. Our study could not establish statistically significant difference in incidence of bacterial growth at different temperatures. Further studies are required to evaluate the effect of temperature on bacterial growth.

\section{Conclusion}

Propofol being lipid emulsion facilitates bacterial growth and edetate, though has inhibitory effects, do not completely prevent bacterial growth. Hence strict aseptic precautions including hand wash and safe injection practices for administration of propofol have to be followed. The gap between what is recommended and what is actually done clinically regarding safe injection practices should be identified and rectified.

48:30-2.

12. Crowther J, Hrazdil J, Jolly DT, Galbraith JC, Greacen M, Grace M. Growth of microorganisms in propofol, thiopental, and a 1: 1 mixture of propofol and thiopental. Anesthesia \& Analgesia. 1996; 82:475-8.

13. M cLeod GA, Pace N, Inglis MD. Bacterial growth in propofol. British Journal of Anaesthesia. 1991; 67:665-6.

14. Sood S, Malhotra M, Das BK, Kapil A. Enterococcal infections \& antimicrobial resistance. Indian J Med Res. 2008; 128:111-21.

15. Edwards DD. Enterococci attract attention of concerned microbiologists. ASM News 2000; 66: 540-5.

16. Low DE, Keller N, Barth A, Jones RN. Clinical prevalence, antimicrobial susceptibility, and geographic resistance patterns of enterococci: results from the SENTRY Antimicrobial Surveillance Program, 1997. 1999. Clin Infect Dis 2001; 32 (Supply 2): S133-45.

17. Schaberg DR, Culver DH, Gaynes RP. Major trends in the microbial etiology of nosocomial infection. AmJ Med 1991; 91: 72S-75S.

18. M urray BE. Diversity among multidrug-resistant enterococci. Emerg Infect Dis 1998; 4: 37-47.

19. L. Silvia M unoz-Price, Robert A. Weinstein Acinetobacter Infection. N Engl J Med 2008; 358:1271-1281

20. Eliopoulos GM, Maragakis LL, Perl TM. Acinetobacter baumannii: epidemiology, antimicrobial resistance, and treatment options. Clinical infectious diseases. 2008; 46:1254-63.

21. Fishbain J, Peleg AY. Treatment of Acinetobacter infections. Clinical infectious diseases. 2010; 51:79-84.

22. Rossolini GM, Mantengoli E. Treatment and control of severe infections caused by multiresistant Pseudomonas aeruginosa. Clinical Microbiology and Infection. 2005; 11(s4):17-32.

23. Morrison AJ, Wenzel RP. Epidemiology of infections due to Pseudomonas aeruginosa. Review of Infectious Diseases. 1984; 6(Supplement 3):S627-42.

24. Pollack M. Pseudomonas aeruginosa. Principles and practice of infectious diseases. 2000; 5:1980-2003. 
25. Shibley GS, Hanger FM, Dochez AR. Studies in the common cold: I. Observations of the normal bacterial flora of nose and throat with variations occurring during colds. The Journal of Experimental Medicine. 1926; 43(3):415.

26. King CA, Ogg M. Safe injection practices for administration of propofol. AORN journal. 2012; 95:365-72.

27. Fukada T, Ozaki M. Microbial growth in propofol formulations with disodium edetate and the influence of venous access system dead space*. Anaesthesia. 2007; 62:575-80. 